\title{
Potential Protective Role of Vitamin E in Lung of Adult Male Albino Rat Exposed to Bisphenol A
}

\author{
HEBA O. MOHAMMED, M.D.*; RADWA M. Al-SAYED, M.D.**; KHALED A. ABULFADLE, M.D.** and \\ AZZA I. FARAG, M.D.* \\ The Departments of Human Anatomy \& Embryology* and Physiology**, Faculty of Medicine, Zagazig University, Egypt
}

\begin{abstract}
Background: Bisphenol A (BPA) is a worldwide manufactured chemical in plastic industry. Exposure to BPA through food and drinking water in plastic containers leads to human health problems.

Aim of Study: This study intends to explore the possible protective role of vitamin E against BPA induced functional and structural changes in the lungs of adult male albino rats.

Material and Method: Twenty four adult male albino rats were divided randomly into 4 equal groups of 6 rats each; Group I (controls) divided into 2 subgroups: Subgroup (A) (negative control group): Fed on regular diet and water for 8 weeks. Subgroup (B) (vehicle control group): Received (1ml of corn oil) by oral gavage/day for 8 weeks. Group II (vitamin E alone) received 200mg Vitamin E/kg/day; Group III (BPA alone) received 500mg BPA/kg/day; Group IV (BPA and vitamin E co-administered) as in groups II and III. The drugs were administered through oral gavage for 8 weeks, at the end of the experiment, heart rate (HR) and mean arterial blood pressure (MABP) were estimated for all the animals. Blood samples were withdrawn for chemical examinations, and after sacrifice fresh lung specimens were collected for histological examination.
\end{abstract}

Results: Administration of Vitamin $\mathrm{E}$ in cooperation with BPA significantly decreased MDA levels, MPO and Caspase3 activities. In addition, it increased GSH, CAT and SOD activities significantly in rat lung tissues. Also, plasma levels of TNF- $\alpha$, IL-1 $\beta$, IL- 6 and LDH were significantly decreased. Blood gases analysis showed no significant difference in $\mathrm{pH}$, but showed increase in $\mathrm{PaO}_{2}$ decrease in $\mathrm{PaCO} 2$ significantly. Moreover hemodynamics changes in the form of significant decrease in MABP and HR. Vitamin E protected lungs against BPA induced histopathological changes like inflammation, congestion, inter alveolar septum thickening, alveolar damage, collagen fibers percent area and fatty infiltration, also the immunohistochemical changes were altered as depicted by significant decrease in the cluster of differentiation 68 (CD68) +ve cell count and decreased expression of nuclear factor kappa B (NF-kB) in immunestained cells of the lung tissue.

Correspondence to: Dr. Heba O. Mohammed, E-Mail: yassin mekkawy@yahoo.com
Conclusion: BPA exposure induced oxidative stress, inflammation and structural lung injury which were significantly less by coadminstration of vitamin E supplementation.

Key Words: Bisphenol A - Oxidative stress - Vitamin ELung.

\section{Introduction}

BISPHENOL A (BPA) is one of the common manufactured chemical products and mostly used in the production of plastic existing in baby bottles, water bottles and food storage containers [1]. It is stable in sediment and is present in nearly all bodies from water and food [2]. Therefore, human exposure to BPA is unavoidable and is expected to continue and even intensify [3]. National Health and Nutrition Inspection Survey [NHANES] reported the level of bisphenol A in urine was about $0.27-10.6 \mathrm{ng} / \mathrm{mL}$ in $90 \%$ of US population [4]. Furthermore, it was reported that daily intake of BPA is around $1 \mathrm{~g} / \mathrm{kg}$ [5].

BPA is same in size and structure as oestradiol; thus, it disrupts endocrine function. Also, it could

\footnotetext{
Abbreviations:

BPA : Bisphenol A.

MDA : Malondialdehyde.

TNF- $\alpha$ : Tumor necrosis factor alpha.

IL-6 : Interlerukin-6.

IL-1 $\beta \quad$ : Interlerukin-1 beta.

NF- $\mathrm{KB}$ : Nuclear factor kappa B.

SOD : Superoxide dismutase.

GSH : Glutathione.

CAT : Catalase.

MPO : Myeloperoxidase.

LDH : Lactate dehydrogenase.

MABP : Mean arterial blood pressure.

HR : Heart rate.

$\mathrm{PaO}_{2}$ : Partial pressure of oxygen.

$\mathrm{PaCO} 2$ : Partial pressure of carbon dioxide.

CD68 : Cluster of differentiation 68.

H \& E : Haematoxylin \& Eosin.
} 
act on oestrogen receptors. However, small amounts of BPA may stimulate hormone-related signalling in the cytoplasm [6]. Most BPA studies have focused on its toxic and endocrine effects on the reproductive system.

Many diseases, such as autoimmune diseases, inflammation and cancer can result from dysregulation of pro-inflammatory cytokines such as nuclear factor kappa B (NF- xB), tumor necrosis factor alpha (TNF- $(\mathrm{X})$, interlerukin-1 beta (IL-1 0$)$, interlerukin 8 (IL8) and interlerukin-6 (IL-6) [7,8,9] .

On the other hand, studies performed on tissue BPA distribution in rats found that it was chiefly concentrated in lung tissue [10]. Thus, chronic BPA exposure could affect lung function due to its accumulation [11].

Vitamin E (Vit E) is one of the fat-soluble vitamins and is abundant in vegetable oils, margarine, nuts and cereal [12]. a-Tocopherol is an active isomer and the most available form of Vit $\mathrm{E}$ in food and supplements. Vit E can trap free radicals which can start the oxidation of lipid chain by direct or indirect way, so it is considered as an antioxidant [13]

Therefore, this study is conducted to reveal the protecting effect of Vit E against BPA induced structural and functional changes of the adult male rat's lungs, aiming to offer a theoretic explanation for the early inhibition of respiratory system impairments induced by administration of BPA. This was achieved using biochemical, histological and immunohistochemical techniques.

\section{Material and Methods}

\section{1- Chemicals:}

1- Bisphenol A: Is an odorless crystalline powder dissolved in corn oil (Sigma, Egypt).

2- Vitamin E: Is oily, has no odor, and dissolved in corn oil. (Safe Pharma Pharco, Pharmaceuticals, Alexandria, Egypt).

3- Corn Oil: Used as a vehicle for bisphenol A and vitamin E (Sekem, Cairo, Egypt).

\section{2- Experimental animals and design:}

The study was carried out on 24 adult male albino rats from animal house (Faculty of Medicine, Zagazig University from December 2018 to April 2019) weighing 180-200g. They were housed in a temperature and humidity controlled clean cages with a constant $12 \mathrm{~h}$ light/dark cycle. Water and food were provided ad libitum. Treatments were started after one week of acclimatization. The study was carried out according to the strategies of ZUIACUC following the rules and guide for the care and use of laboratory animals 8 th Edition 2011 (The number of IACUC approval ZU-IACUC/3/F/ 65/2018).

Rats were randomly separated into 4 groups of 6 rats each:

- Group I (control group) divided into 2 subgroups: Subgroup (A) (negative control group): 3 rats fed on regular diet and water for 8 weeks.

- Subgroup (B) (vehicle control group): 3 rats received ( $1 \mathrm{ml}$ of corn oil) as the vehicle of BPA and vitamin $\mathrm{E}$ by oral gavage/day for 8 weeks.

- Group II (vitamin E administered group) each rat received oral gavage of $200 \mathrm{mg} / \mathrm{kg}$ Vit E/day, dissolved in corn oil, for 8 weeks [14].

- Group III (bisphenol A administered group) each rat received oral gavage of $500 \mathrm{mg} / \mathrm{kg} /$ day of BPA, dissolved in corn oil, for 8 weeks [15] Selection of dose was done on the basis of the LD50 value of BPA (oral LD50 for rats was $5000 \mathrm{mg} / \mathrm{kg}$ ) [16].

- Group IV (bisphenol A and vitamin E administered group) each rat received oral gavage of $(200 \mathrm{mg} /$ $\mathrm{kg}$ Vit E then (500mg/kg BPA)/day, both dissolved in corn oil, for 8 weeks.

Heart rate $(H R)$ and mean arterial blood pressure $(M A B P)$ measurement:

At the end of the experiment, the non-invasive method was used (NIBP; 250 systems, BioPAC system, INC.) to monitor the blood pressure and heart rate as described by Abubakar et al. [17]

$\mathrm{MABP}=$ Diastolic pressure +

(systolic pressure - Diastolic pressure)/3.

\section{Collection of samples:}

Blood samples were collected in heparinized tubes from vein of rat tail; plasma was separated by centrifugation at $3000 \mathrm{rpm}$ for $15 \mathrm{~min}$ and was kept at $20^{\circ} \mathrm{C}$ till used. The animals were then sacrificed by cervical dislocation, the chest walls were opened and lung samples were collected for biochemical, histopathological and immunohistochemical examinations [18]

\section{Lung function evaluation:}

It was evaluated by analyzing the levels of $\mathrm{pH}$, partial pressure of both oxygen $\left(\mathrm{PaO}_{2}\right)$ and carbon dioxide $\left(\mathrm{PaCO}_{2}\right)$ in the plasma using an arterial blood gas analyzer. 


\section{Lung homogenate preparation:}

The right lung of each animal was homogenized $(50 \mathrm{mM})$ in ice-cold sodium phosphate buffer containing (0.1mM, pH 7.4) EDTA. The supernatant separated by centrifugation for $20 \mathrm{~min}$ at $4^{\circ} \mathrm{C}$ [19], was used for biochemical examination of malondialdehyde (MDA), superoxide dismutase (SOD), glutathione (GSH), catalase (CAT), myeloperoxidase (MPO) and caspases-3 activities.

\section{Redox status of lung:}

MDA, SOD and GSH levels, and CAT activities were measured using ELISA kits (Biodiagnostic, Giza, Egypt) according to Ohkawa et al. [20], Kakkar et al. [21], Luck [22] and Reddy et al. [23] respectively.

\section{Inflammatory cytokines measurements:}

They plasma inflammatory cytokines were measured by using commercially available ELISA kits for TNF- $\alpha$, IL- 6 and IL-1 $\beta$ (Biodiagnostic, Cairo, Egypt), as per manufacturer's instructions.

\section{MPO activity measurement:}

It was measured using commercial kit (Biodiagnostic, Cairo, Egypt) in agreement with the protocol of the manufacturer.

\section{Lactate dehydrogenase ( $\mathrm{LDH}$ ) activity meas-} urement:

Plasma LDH activity was determined using a commercial ELISA kit (Biodiagnostic, Cairo, Egypt) according to the instructions of manufacturer.

\section{Apoptosis marker evaluation:}

Caspases 3 activity was measured by specific colorimetric assays (Biodiagnostic, Cairo, Egypt) following manufacturer's instructions.

\section{Histological study:}

Specimens were fixed in $10 \%$ normal saline and processed to prepare 5- m-thick paraffin sections which were deparaffinized, rehydrated and stained with:

1- Haematoxylin \& Eosin (H \& E) stain [24] to detect variations in the morphology.

2- Mallory trichrome stain [25] to detect distribution of collagen fibres.

3- Immunohistochemical stains for detection of activated NF- $\kappa \mathrm{B}$ and cluster of differentiation 68 (CD68). All specimens were processed by using the method of avidin-biotin-peroxidase. Sections of 4- mickness were dewaxed in xylene, rehydrated in a descending grade of ethanol, and then immersed in $0.3 \% \mathrm{H}_{2} \mathrm{O}_{2}$ for $30 \mathrm{~min}$ to block endogenous peroxidase activity. Antigens were retrieved in citrate buffer $(\mathrm{pH}$ 6.0 ) by microwaving for $15 \mathrm{~min}$. Nonspecific binding was blocked with $10 \%$ goat serum (Dako Ltd, Cambridgeshire, UK) for 30min. The sections were immunostained with primary antibody $(1 \mathrm{~g} / \mathrm{mL}$ rabbit polyclonal $\mathrm{IgG}$ to rat NF- $\kappa B$ (obtained from Sigma) in TBS with 5\% BSA overnight at $4{ }^{\circ} \mathrm{C}$. Slides were washed with TBS, and then added goat anti-rabbit to the slides. After incubation, the sections were washed with TBS and then incubated for 5$10 \mathrm{~min}$ in $0.02 \%$ diaminobenzidine containing $0.01 \%$ hydrogen peroxide. The slides were counterstained with hematoxylin. Macrophages were detected with a mouse monoclonal antibody against CD68 (1:100 dilution; NCL-LCD68; Leica Biosystems Newcastle Ltd., UK). The sections were incubated with biotinylated anti-rabbit or anti-mouse immunoglobulin (Dako Ltd, Cambridgeshire, UK) and with the avidinbiotin-horseradish peroxidase complex according to the manufacturer's instructions $[26,27]$.

\section{Morphometric study:}

A computerized image analyzer (Leica Imaging System Ltd., Cambridge, England) in the Image Analyzing Unit of Human Anatomy and Embryology Department, Faculty of Medicine, Zagazig University, Egypt was used to measure the interalveolar septum thickness in H\&E-stained sections and the percent of collagen area in Mallory's trichrome-stained sections. Moreover, CD68+ve cells were counted in sections stained with anti CD68 and NFKB immune stained sections were analyzed to calculate the area percentage of positive immuno reaction for $\mathrm{NF} \kappa \mathrm{B}$. The image analyzer converted the measurement units (pixels) into micrometers automatically by calibration. Ten readings were obtained for each specimen, and the mean was calculated. The measured data were taken at $400 \mathrm{x}$ magnification in ten non overlapping fields from 5 sections per rat in each group using the interactive measurement menu.

\section{Statistical analysis:}

The data obtained are represented as mean \pm standard deviation (SD) for quantitative variables and analyzed statistically by using program of SPSS (version 18 for windows) (SPSS Inc. Chicago, IL, USA). The results of all examined groups were compared by One-way Analysis of Variance (ANOVA) followed by LSD test to compare statistical differences between the groups. $p$-value $\leq 0.05$ is considered statistically significant [28]. 


\section{Results}

Mean arterial blood pressure, heart rate in rats of all studied groups: Though no statistically significant differences between the groups I and II was observed, but a statistically significant increase between them and group III and IV were found. Also, there was a statistically significant decrease in both heart rate and arterial blood pressure between group III\&IV (Table 1).

Blood gases analysis showed that: No statistically significant differences in $\mathrm{PaO}_{2}$ between the groups I\&II were found but there was a statistically significant decrease in both III\&IV groups than other groups. Also, a statistically significant increase in group IV than III was seen (Table 1). As regard $\mathrm{PaCO} 2$, no statistically significant difference in $\mathrm{PaCO}_{2}$ between the groups I\&II was found but a statistically significant increase in both IV \&III groups was noticed. Also, a statistically significant decrease in group IV than III was found (Table 1). Blood $\mathrm{pH}$ showed no statistical difference between all the groups.

Table (1): Blood gases, mean arterial blood pressure and heart rate changes in different groups.

\begin{tabular}{|c|c|c|c|c|}
\hline Group & Group I & Group II & Group III & Group IV \\
\hline Variable & Mean \pm SD & Mean \pm SD & Mean \pm SD & Mean \pm SD \\
\hline $\mathrm{PaO}_{2}(\mathrm{mmHg})$ & $104 \pm 1.5$ & $\begin{array}{l}109 \pm 1.4 \\
\mathrm{NSa}\end{array}$ & $\begin{array}{l}77.8 \pm 2.2 \\
p<0.001 \mathbf{a , b}\end{array}$ & $\begin{array}{l}80.8 \pm 1.9 \\
p<0.001 \mathbf{a}^{\mathbf{a}} \mathbf{b}, p<0.01 \mathbf{c}\end{array}$ \\
\hline $\mathrm{PaCO} 2(\mathrm{mmHg})$ & $10.65 \pm 1.32$ & $\begin{array}{l}10.78 \pm 1.36 \\
\mathrm{NSa}\end{array}$ & $\begin{array}{c}33.64 \pm 3.49 \\
p<0.001 \mathbf{a , b}\end{array}$ & $\begin{array}{l}27.33 \pm 2.17 \\
p<0.001 \mathbf{a}^{\prime} \mathbf{b}, p<0.01 \mathbf{c}\end{array}$ \\
\hline $\mathrm{pH}$ & $7.44 \pm 0.01$ & $\begin{array}{l}7.46 \pm 0.02 \\
\mathrm{NSa}\end{array}$ & $\begin{array}{l}7.43 \pm 0.03 \\
\mathrm{NS}^{\mathbf{a}^{\prime} \mathbf{b}}\end{array}$ & $\begin{array}{l}7.43 \pm 0.01 \\
\text { NS a a,b,c }\end{array}$ \\
\hline MABP (mmHg) & $122.23 \pm 4.56$ & $\begin{array}{l}119.43 \pm 3.27 \\
\text { NSa }\end{array}$ & $\begin{array}{l}154.95 \pm 5.82 \\
p<0.001 \mathbf{a}, \mathbf{b}\end{array}$ & $\begin{array}{l}132.76 \pm 3.55 \\
p<0.001 \mathbf{a , b , c}\end{array}$ \\
\hline Heart rate (beat/min) & $324.5 \pm 15.98$ & $\begin{array}{l}315.5 \pm 19.36 \\
\text { NS a }\end{array}$ & $\begin{array}{l}565.5 \pm 15.17 \\
p<0.001 \mathbf{a , b}\end{array}$ & $\begin{array}{l}410.8 \pm 11.06 \\
p<0.001 \mathbf{a , b , c}\end{array}$ \\
\hline
\end{tabular}

NS $=$ Non-significant $(p>0.05) . \quad \mathbf{a}=$ Versus group-I. $\quad \mathbf{b}=$ Versus group-II. $\quad \mathbf{c}=$ Versus group-III.

\section{MDA, SOD, GSH and CAT levels:}

There were no statistically significant differences in the levels of MDA between group I\&II, but there was a statistically significant increase in both groups III\&IV as compared to group I\&II (Table 2 \& Fig. 1). Also, a statistically significant decrease in the levels of MDA was found in group IV in comparison to group III indicating a preventive role of vitamin E. Regarding SOD, GSH and CAT, there was no statistically significant difference between the groups I\&II but a statistically signif- icant decrease in both the groups III\&IV was detected. On the other hand, these parameters were significantly increased in group IV than in group III (Table 2).

\section{MPO and Caspase-3 levels:}

No statistically significant differences between the groups I\&II were found but there was a statistically significant increase in both III\&IV groups. Also, a statistically significant decrease in group IV than in group III was observed (Table 2).

Table (2): Changes in MDA, SOD, GSH, CAT, MPO and Caspase-3 levels in rat lung tissues in different groups.

\begin{tabular}{|c|c|c|c|c|}
\hline Group & Group I & Group II & Group III & Group IV \\
\hline Variable & Mean \pm SD & Mean \pm SD & Mean \pm SD & Mean \pm SD \\
\hline MDA (nmol/g protein) & $3.21 \pm 0.62$ & $\begin{array}{l}3.36 \pm 0.75 \\
\mathrm{NSa}\end{array}$ & $\begin{array}{l}9.98 \pm 0.82 \\
p<0.001 \mathbf{a , b}\end{array}$ & $\begin{array}{l}6.20 \pm 0.63 \\
p<0.001 \mathbf{a}, \mathbf{b}, \mathbf{c}\end{array}$ \\
\hline SOD (U/g protein) & $6.23 \pm 0.89$ & $\begin{array}{l}6.38 \pm 0.63 \\
\mathrm{NSa}\end{array}$ & $\begin{array}{l}4.54 \pm 0.87 \\
p<0.001 \mathbf{a}, \mathbf{b}\end{array}$ & $\begin{array}{l}5.98 \pm 0.7 \\
p<0.001 \mathbf{a , b}, \mathbf{c}\end{array}$ \\
\hline GSH ( rmal/g protein) & $30.43 \pm 1.56$ & $\begin{array}{l}32.49 \pm 1.98 \\
\mathrm{NSa}\end{array}$ & $\begin{array}{l}19.93 \pm 1.91 \\
p<0.001 \mathbf{a , b}\end{array}$ & $\begin{array}{l}23.25 \pm 1.25 \\
p<0.001 \mathbf{a , b}, \mathbf{c}\end{array}$ \\
\hline CAT (U/ mg protein) & $1.27 \pm 0.17$ & $\begin{array}{l}1.31 \pm 0.19 \\
\mathrm{NSa}\end{array}$ & $\begin{array}{l}0.61 \pm 0.10 \\
p<0.001 \mathbf{a , b}\end{array}$ & $\begin{array}{l}0.95 \pm 0.13 \\
p<0.001 \mathbf{a}, \mathbf{b}, \mathbf{c}\end{array}$ \\
\hline MPO (U/g protein) & $21.73 \pm 3.06$ & $\begin{array}{l}18.73 \pm 3.85 \\
\mathrm{NSa}\end{array}$ & $\begin{array}{l}74.54 \pm 5.87 \\
p<0.001 \mathbf{a , b}\end{array}$ & $\begin{array}{l}43.65 \pm 4.85 \\
p<0.001 \mathbf{a , b}, \mathbf{c}\end{array}$ \\
\hline Caspase-3 (U/ g/cotein) & $213.53 \pm 13.06$ & $\begin{array}{l}200.13 \pm 10.06 \\
\mathrm{NSa}\end{array}$ & $\begin{array}{l}391.73 \pm 9.86 \\
p<0.001 \mathbf{a , b}\end{array}$ & $\begin{array}{l}312.53 \pm 12.36 \\
p<0.001 \mathbf{a , b , c}\end{array}$ \\
\hline
\end{tabular}

NS $=$ Non-significant $(p>0.05) . \quad \mathbf{a}=$ Versus group-I. $\quad \mathbf{b}=$ Versus group-II. $\quad \mathbf{c}=$ Versus group-III. 


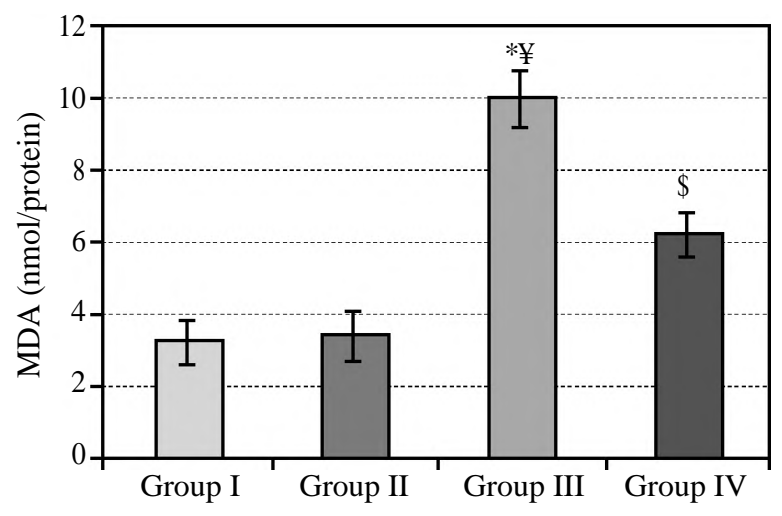

$T N F-\alpha, I L-1 \beta, I L-6$ and $L D H$ levels in the plasma of rats:

no statistically significant differences between both I\&II groups were found but there was a sta-
Fig. (1): MDA level changes in different groups.

- Data was expressed as Mean \pm SD.

- Data was expressed as Mean \pm SD.

- * $p<0.001$ statistically significant compared with the corresponding value in group $\mathrm{I}$.

- $¥ p<0.001$ statistically significant compared with the corresponding value in group II.

- $\$ p<0.001$ statistically significant compared with the corresponding value in group III.

Table (3): Changes in plasma levels of TNF- $\alpha$, IL-1 $\beta$, IL-6 and LDH in different groups.

\begin{tabular}{|c|c|c|c|c|}
\hline Group & Group I & Group II & Group III & Group IV \\
\hline Variable & Mean \pm SD & Mean \pm SD & Mean \pm SD & Mean \pm SD \\
\hline TNF- $\alpha(\mathrm{pg} / \mathrm{ml})$ & $57.17 \pm 3.77$ & $\begin{array}{l}55.32 \pm 2.09 \\
\mathrm{NSa}\end{array}$ & $\begin{array}{l}83.16 \pm 1.94 \\
p<0.001 \mathbf{a , b}\end{array}$ & $\begin{array}{l}64.23 \pm 2.06 \\
p<0.001 \mathbf{a , b}, \mathbf{c}\end{array}$ \\
\hline IL-1 $\beta(\mathrm{pg} / \mathrm{ml})$ & $30.92 \pm 6.14$ & $\begin{array}{l}34.76 \pm 5.42 \\
\mathrm{NSa}\end{array}$ & $\begin{array}{l}102.34 \pm 12.05 \\
p<0.001 \mathbf{a}, \mathbf{b}\end{array}$ & $\begin{array}{l}83.27 \pm 8.28 \\
p<0.001 \mathbf{a , b}, \mathbf{c}\end{array}$ \\
\hline IL-6 (pg/ml) & $12.57 \pm 2.41$ & $\begin{array}{l}10.57 \pm 1.69 \\
\mathrm{NSa}\end{array}$ & $\begin{array}{l}44.46 \pm 3.51 \\
p<0.001 \mathbf{a , b}\end{array}$ & $\begin{array}{l}22.5 \pm 2.27 \\
p<0.001 \mathbf{a , b}, \mathbf{c}\end{array}$ \\
\hline LDH (U/L) & $52.5 \pm 4.85$ & $\begin{array}{l}47.32 \pm 2.09 \\
\mathrm{NSa}\end{array}$ & $\begin{array}{l}90.64 \pm 5.05 \\
p<0.001 \mathbf{a , b}\end{array}$ & $\begin{array}{l}73.27 \pm 8.28 \\
p<0.001 \mathbf{a , b}, \mathbf{c}\end{array}$ \\
\hline
\end{tabular}

NS $=$ Non-significant $(p>0.05) . \quad \mathbf{a}=$ Versus group-I. $\quad \mathbf{b}=$ Versus group-II. $\quad \mathbf{c}=$ Versus group-III.

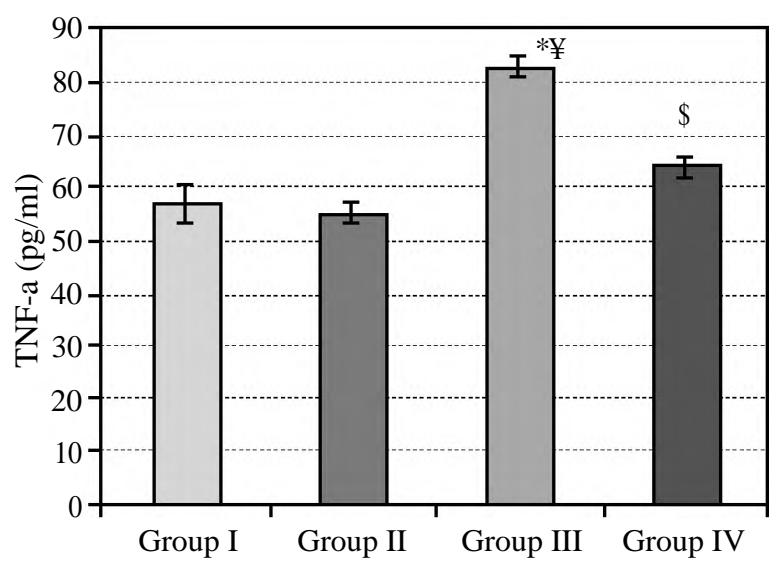

\section{Histological examination:}

\section{$H \&$ E stain:}

An examination of lung tissue sections from group I (control group) and group II (vitamin Eadministered group) showed normal architecture of lung, inflated alveoli, alveolar sacs, bronchioles, and blood vessels. Type I pneumocyte appeared as flat cells in the alveolar wall lining and type II tistically significant increase in both III\&IV groups than other groups. Also, a statistically significant decrease in group IV than group III was explored (Table 3 \& Fig. 2). 
cell infiltrations were present. Blood vessels were dilated and congested with a markedly thickened wall. Red blood cells (RBCs) were extravasated in the alveolar cavity and the interstitium (Fig. $\left.3 \mathrm{~B}, \mathrm{~B}^{*}, 4 \mathrm{~B}\right)$.
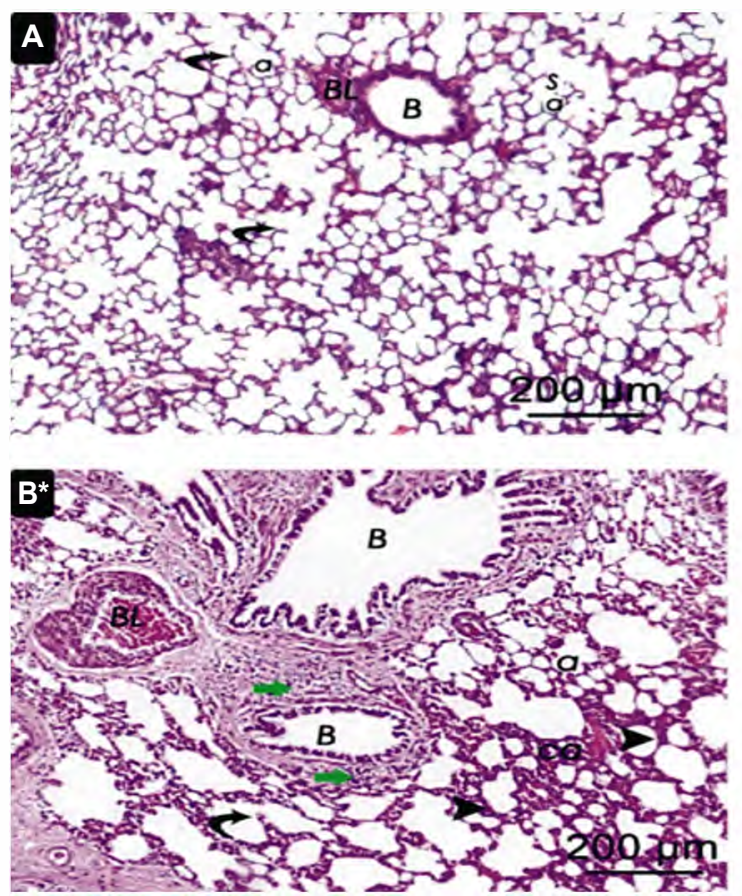

The co-administration of BPA and Vit E (group IV) maintained almost normal lung tissue, with relatively thin walled and inflated alveoli. However, some extravasated RBCs and inflammatory cell infiltration were detected (Fig. 3C,4C).
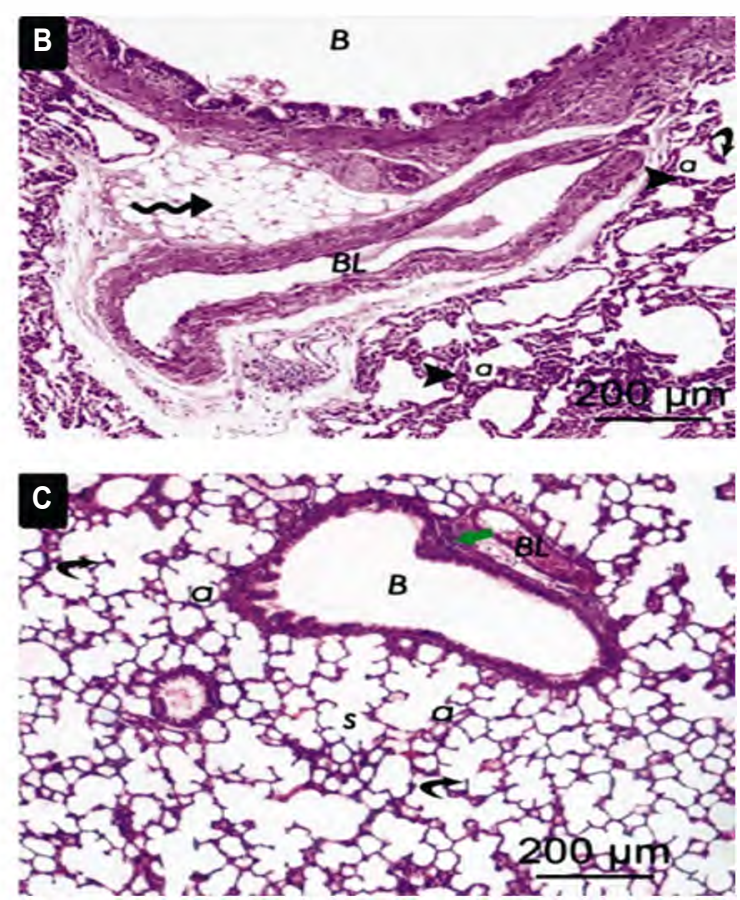

Fig. (3): A photomicrograph of a lung tissue section. (A) Normal lung tissue in the control group have thin-walled, inflated alveoli (a) open into alveolar sacs (S) and thin interalveolar septa (curved arrow), bronchiole (B) and blood vessel (BL). (B \& B*) Group III show dilated and congested blood vessels (BL) with thickened walls and a dilated and thick-walled bronchiole (B) with fatty infiltration (zigzag arrow) and inflammatory cell infiltration (green arrow). Some alveoli are collapsed (ca), while others are dilated (a) with thickened walls (arrowhead) and thick interalveolar septa (curved arrow). (C) Group IV shows normal lung structure with thin-walled and inflated alveoli (a) open into alveolar sacs (S), thin interalveolar septa (curved arrow), a normal bronchiole (B) with some inflammatory cell infiltration (green arrow) and a mildly congested, thick-walled blood vessel (BL). (H\&E, 100x).
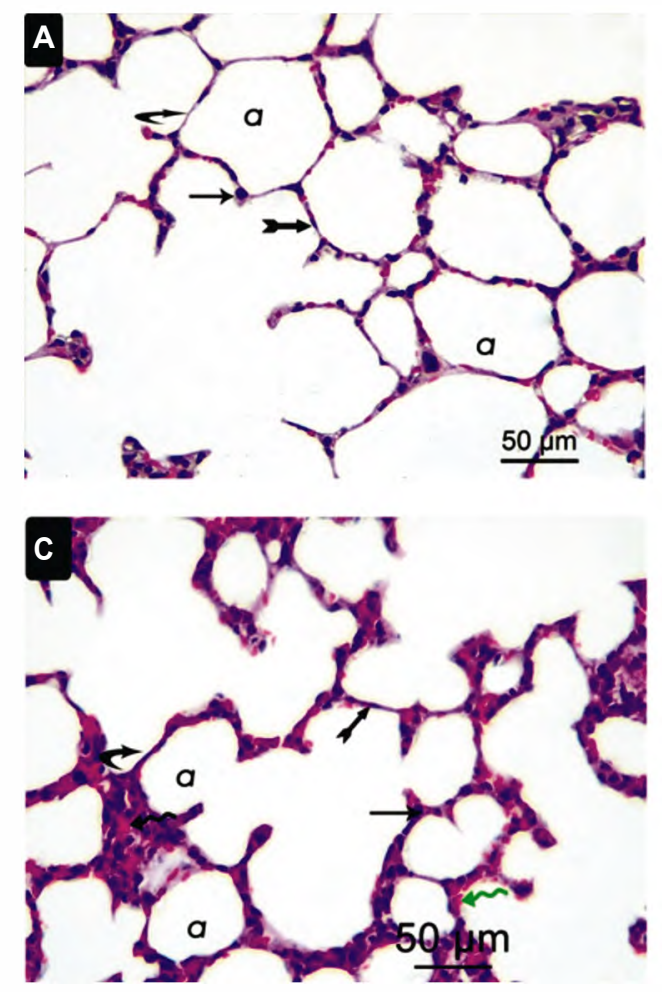

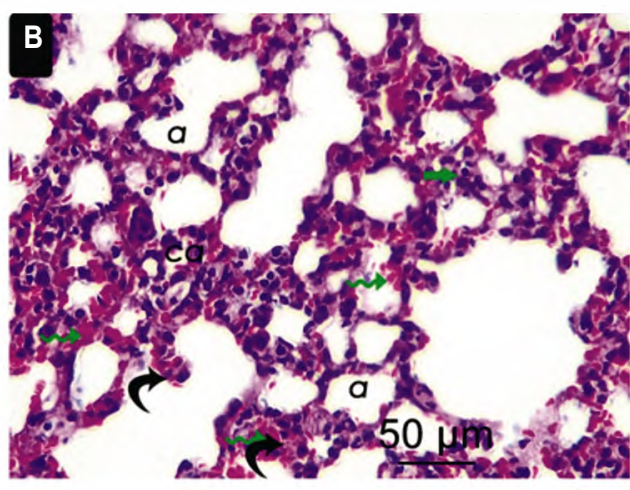

Fig. (4): A photomicrograph of a lung tissue section. (A) Normal lung tissue in the control group with thin-walled, inflated alveoli. (a) Thin interalveolar septa (curved arrow) is lined by flat type I pneumocytes (tailed arrow) and cuboidal type II pneumocytes (thin arrow). (B) Group III have inflated alveoli (a) with a thick wall (curved arrow); other alveoli are collapsed (ca), and marked extravasation of RBCs in the lumen of alveoli and interstitium (green zigzag arrow) is evident. (C) Group IV has nearly normal lung structure with thin-walled, inflated alveoli (a), thin interalveolar septa (curved arrow) are lined with flat type I pneumocytes (tailed arrow) and cuboidal type II pneumocytes (thin arrow) and a few extravasated RBCs (zigzag green arrow) in the alveolar wall. (H\&E, 400x) 


\section{Mallory's trichrome stain:}

The examination of the groups (I \& II) showed the minimal distribution of collagen fibers in both the bronchiole and blood vessel walls, with even fewer fibers in interalveolar septa (Fig. 5A). In the lung tissue from group III, marked deposition of

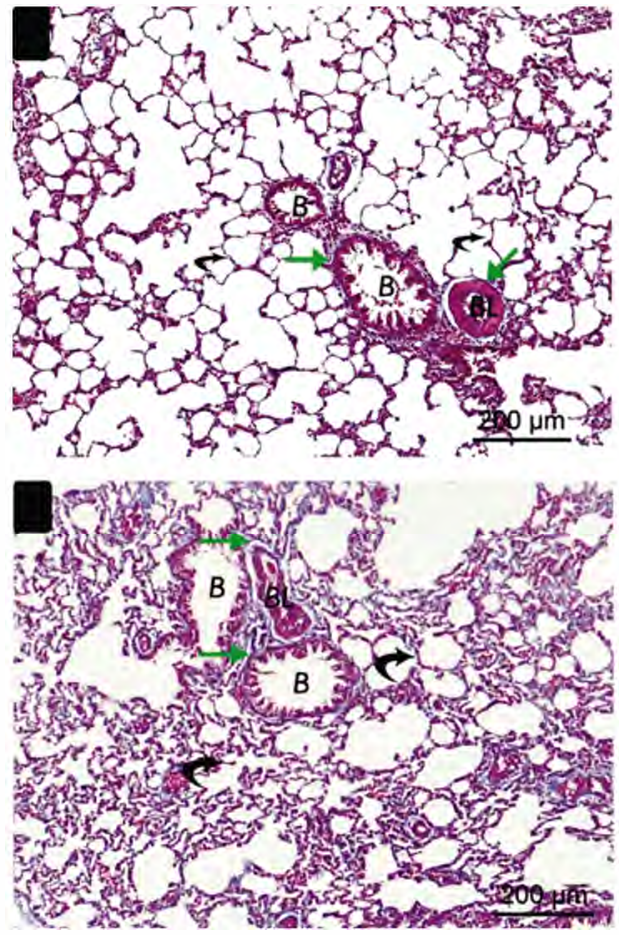

Immunohistochemical stain:

For $N F-\kappa B$ :

Lung sections from animals in groups I and II showed minimal intracellular NF- $\kappa$ B staining (Fig.
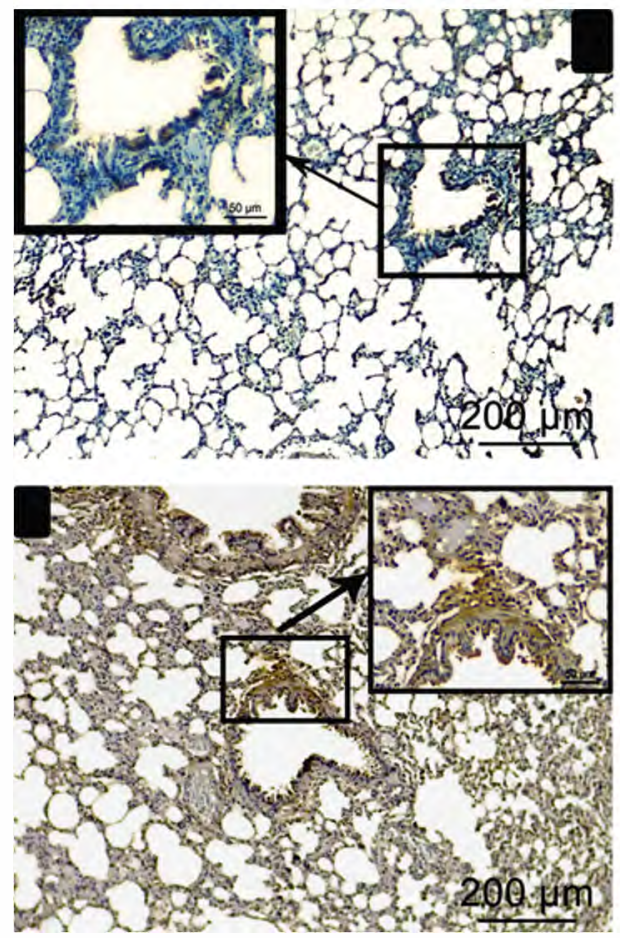

collagen fiber was evident in interalveolar septa and the bronchiole wall, with more prominent deposits in the blood vessel wall (Fig. 5B). While, the collagen fiber deposition in lung sections from group IV was moderate in amount and distribution (Fig. 5C).

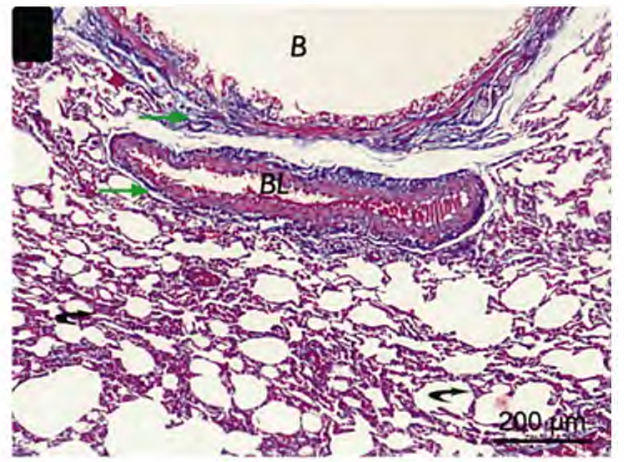

Fig. (5): A photomicrograph of lung tissue sections. (A) Groups I and II: show minimal collagen deposition (green arrow) around blood vessels (BL), a bronchiole (B) and the alveolar wall (curved arrow). (B) Group III: Shows excessive collagen deposition (green arrow) around blood vessels (BL), a bronchiole (B) and the alveolar wall (curved arrow). (C) Group IV: shows moderate collagen deposition (green arrow) around blood vessels (BL), a bronchiole (B) and the alveolar wall (curved arrow). (Mallory's trichrome, x 100).

$6 \mathrm{~A})$. In group III, lung tissue showed high NF- $\kappa \mathrm{B}$ expression, as detected by the dark brown staining of NF- $\kappa \mathrm{B}$-immunopositive cells (Fig. 6B); fewer such cells were present in specimens from group IV (Fig. 6C).

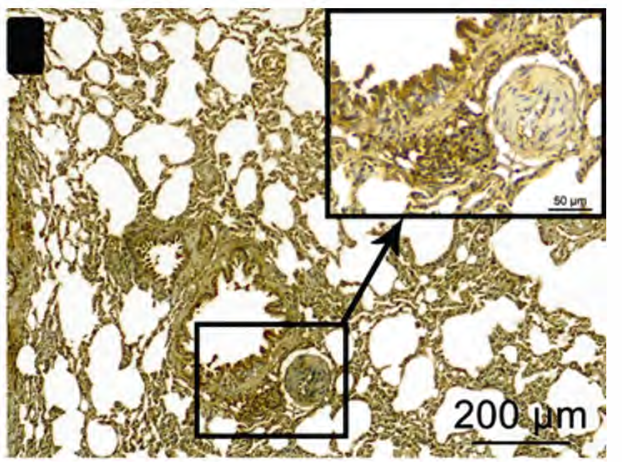

Fig. (6): A photomicrograph of lung tissue sections. (A) Groups I and II have minimal NF- $\kappa \mathrm{B}$ expression. (B) Group III shows high NF- $\kappa$ B expression in lung cells. (C) Group IV shows moderate $\mathrm{NF}-\kappa \mathrm{B}$ expression. (NF- $\kappa \mathrm{B}, 100 \mathrm{x}$ and $400 \mathrm{x}$ ). 


\section{For CD68:}

Lung sections from animals in groups I and II showed a normal distribution of relatively few alveolar macrophages, which appear as brown stained cells in interalveolar septa (Fig. 7A). How-

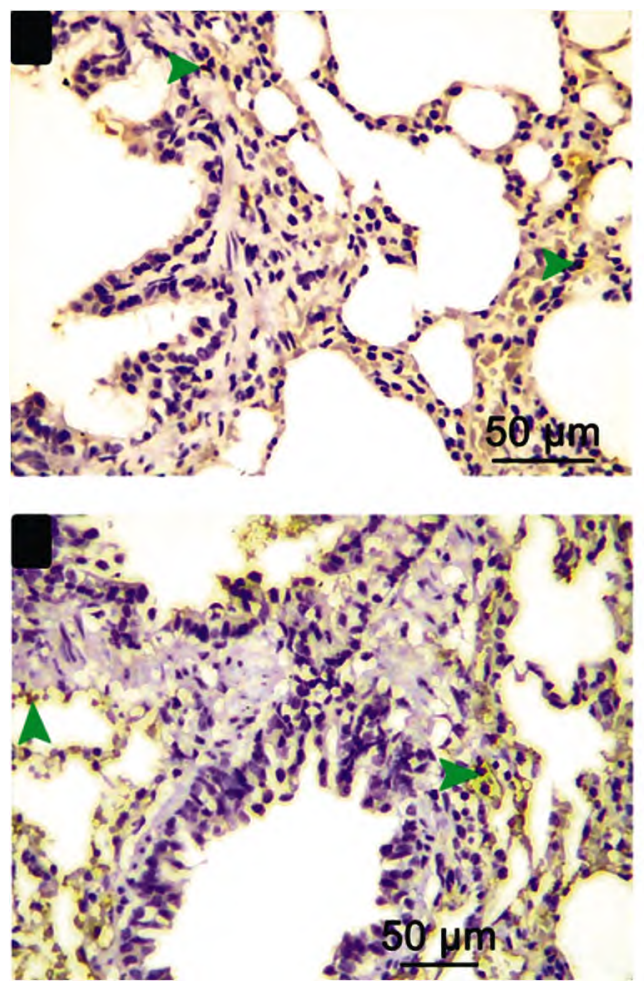

Morphometric results of thickness of interalveolar septum, area percent of collagen fibrs, the count of alveolar macrophages and area percent of $N F-\kappa B$ immunestaining:

There were no statistical significant differences between groups (I\&II) considering the interalveolar septum thickness, the area percent of collagen deposition, the count of alveolar macrophages and area percent of immune positive NF $\kappa \mathrm{B}$. Although, there was a high statistically significant increase ever, the number of positively stained macrophages in interalveolar septa and bronchial wall was markedly increased in group III (Fig. 7B). The distribution of these cells tended to return to normal in group IV (Fig. 7C).

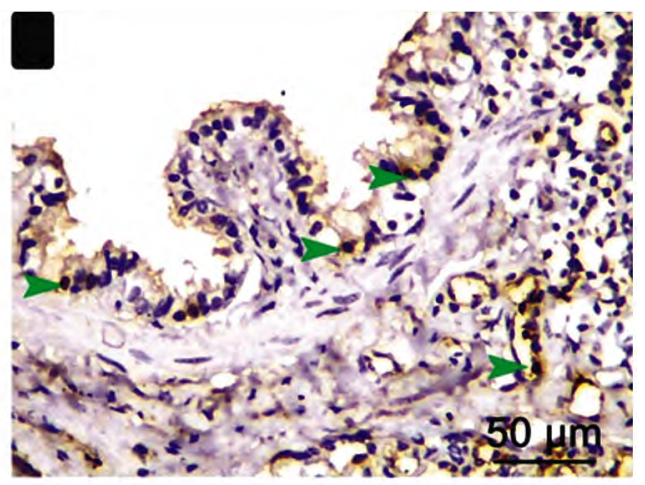

Fig. (7): A photomicrograph of lung tissue sections. (A) Groups I and II have a few CD68positive cells (green arrowhead). (B) Group III shows a marked increase in positively stained cells. (C) Group IV has fewer positively stained cells. (CD68, 400x)

in group (III) regarding previous parameters in comparison with all the other groups. Group (IV) showed a high statistically significant increase as compared to the groups (I\&II) but significantly less than group (III) regarding interalveolar thickness and area percent of immune positive NF $\kappa B$. Moreover, group (IV) showed non-significant difference in comparison to group (I\&II) regarding the area percent of collagen deposition and the count of alveolar macrophages (Table $4 \&$ Figs. 8, $9,10)$.

Table (4): The mean thickness of interalveolar septum (thickness um), area percent of collagen fibers (collagen area \%), the count of alveolar macrophages (Count) and area percent of NF- $\kappa \mathrm{B}$ immunestaining (NF$\kappa \mathrm{B}$ area\%) in the different groups. Data was expressed as Mean \pm SD. Number of rats $=6 \mathrm{SD}$ : Standard deviation.

\begin{tabular}{|c|c|c|c|c|}
\hline Group & Group I & Group II & Group III & Group IV \\
\hline Variable & Mean $\pm S D$ & Mean \pm SD & Mean \pm SD & Mean $\pm S D$ \\
\hline Thickness (um) & $0.31 \pm 0.10$ & $\begin{array}{l}0.33 \pm 0.07 \\
\mathrm{NSa}\end{array}$ & $\begin{array}{l}0.84 \pm 0.19 \\
p<0.001 \mathbf{a , b}\end{array}$ & $\begin{array}{l}0.60 \pm 0.20 \\
p<0.001 \mathbf{a , b}, \mathbf{c}\end{array}$ \\
\hline Collagen area\% & $10.58 \pm 6.98$ & $\begin{array}{l}10.6 \pm 6.97 \\
\mathrm{NSa}\end{array}$ & $\begin{array}{l}31.01 \pm 10.09 \\
p<0.001 \mathbf{a , b}\end{array}$ & $\begin{array}{l}15.37 \pm 8.38 \\
\text { NS } \mathbf{a}^{\prime} \mathbf{b} \& p<0.001 \mathbf{c}\end{array}$ \\
\hline Count & $1.61 \pm 0.63$ & $\begin{array}{l}2.41 \pm 0.99 \\
\mathrm{NSa}\end{array}$ & $\begin{array}{l}9.16 \pm 2.31 \\
p<0.001 \mathbf{a , b}\end{array}$ & $\begin{array}{l}4.05 \pm .59 \\
\text { NSa'b \& } p<0.001 \mathbf{c}\end{array}$ \\
\hline$(\mathrm{NF}-\kappa \mathrm{B}$ area $\%)$ & $7.03 \pm 2.04$ & $\begin{array}{l}6.681 \pm 1.81 \\
\text { NSa }\end{array}$ & $\begin{array}{l}39.03 \pm 5.78 \\
p<0.001 \mathbf{a}, \mathbf{b}\end{array}$ & $\begin{array}{c}14.73 \pm 4.78 \\
p<0.001 \mathbf{a , b , c}\end{array}$ \\
\hline
\end{tabular}

NS $=$ Non-significant $(p>0.05) . \quad \mathbf{a}=$ Versus group-I. $\quad \mathbf{b}=$ Versus group-II. $\quad \mathbf{c}=$ Versus group-III. 


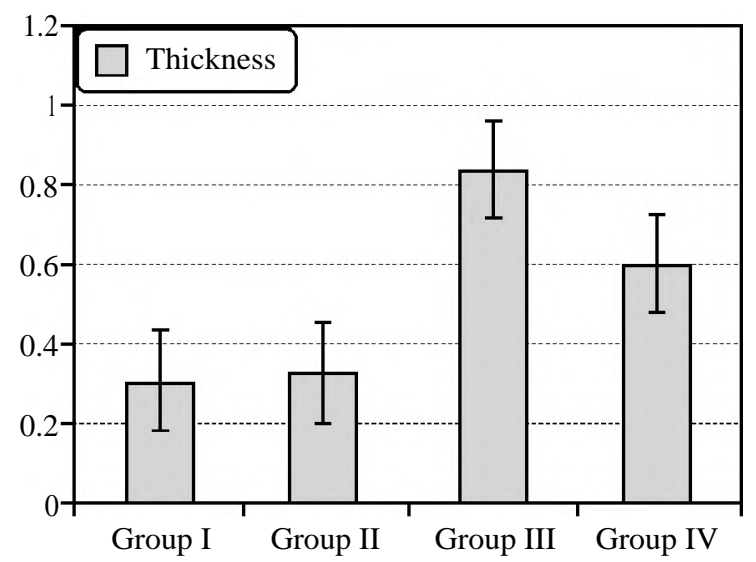

Fig. (8): Thickness of interalveolar thickness of all groups.

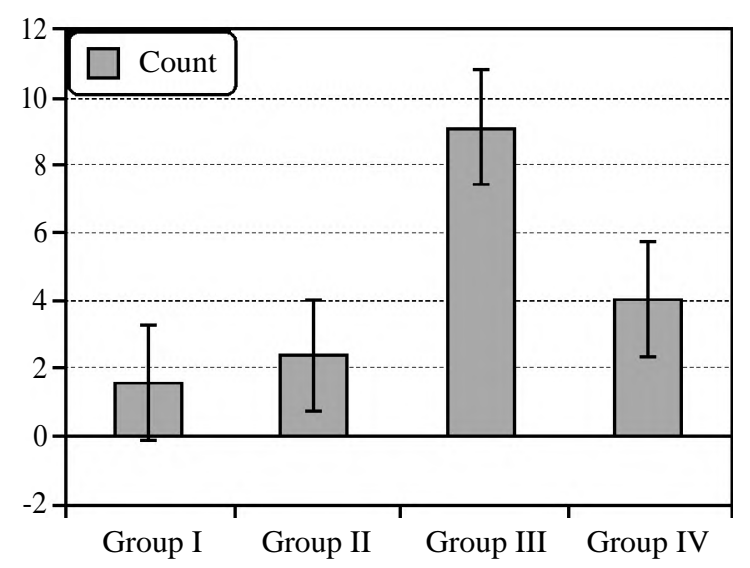

Fig. (9): Count of CD68 +ve cells of all groups.

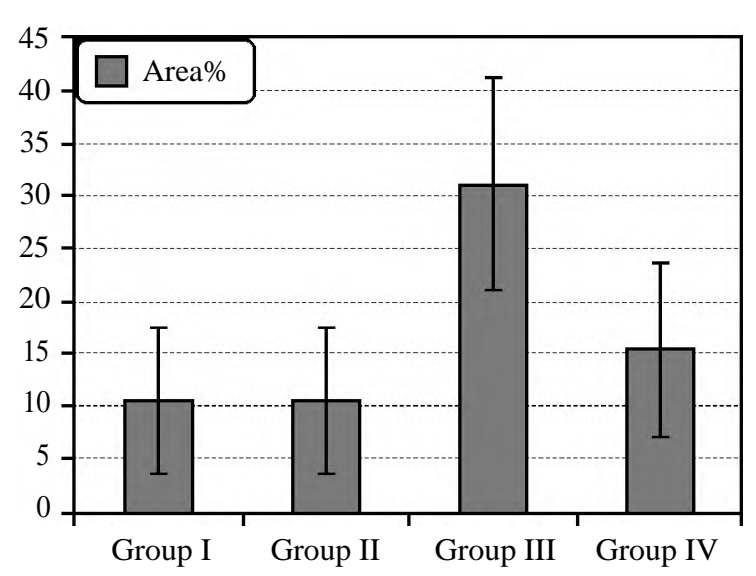

Fig. (10): Area percent of collagen of all groups.

\section{Discussion}

The current study proposes that oxidative stress is the main cause of bisphenol A induced functional, histological and immunohistochemical alterations via inhibition of the antioxidant enzymes activities leading to reactive oxygen species (ROS) accumulation resulting into lung tissue injury. Consequently, this study explored the possible underlying mechanisms involved in the inhibitory effect of vitamin $\mathrm{E}$ on BPA induced lung injury and inflammation and illustrated the biochemical, histopathological and immunohistochemical changes in BPAinduced possible lung diseases.

Oxidative stress is a state of imbalance between antioxidants and oxidants in favor of oxidants causing a significant cellular damage and development of many diseases [29]. Geetharathan et al. [30] suggested that BPA induced oxidative stress and ROS generation exceeded the ability of intracellular antioxidant system and is considered the root of different inflammatory, asthmatic and chronic obstructive pulmonary diseases (COPD) [31]

This study revealed a significant elevation in MDA level and a significant reduction in SOD, GSH and CAT levels in BPA treated group (III) consistent with Song et al. [32] and Abedelhaffez, El-Aziz et al. [33]. MDA represented the main product of lipid peroxidation and caused cellular destruction owing to its ability to bind with important biomolecules like proteins, lipids and nucleic acids [34] . On the other side, GSH is the freely accessible antioxidant and it acts as antioxidant either directly or indirectly by taking part in catalytic sequences of antioxidant enzymes [35]. Thiol group in the structure of glutathione discharges the hydrogen atom in the free radicals, so; it protects cell membranes [36]. Sabour et al. [37] showed that BPA decreased serum GSH level, which is a marker of oxidative stress.

As Vit E is a [fat-soluble vitamin] and lipids constitute about $90 \%$ of the surfactant, it could prevent the ROS damage by enhancing the activity of SOD, GSH and total antioxidant capacity [38] These results were parallel to those of Amraoui et al. [39] who stated that the protecting effect of vitamin $E$ is due to increase in the activities of antioxidant enzymes and reduction of lipid peroxidation, as shown in group IV. In addition, earlier studies verified the vital effects of vitamin E together with selenium in decreasing lipid peroxidation [40].

In this study, BPA intake markedly disturbed the lung structure, as shown by the inflammatory cell infiltration, alveolar collapse, thickening and congestion of the lung vasculature, fatty cell infiltration and RBC extravasation in the alveolar cavity and interstitium. These effects were in agreement with the results of Amaravathi, et al. [41], Kattaia and Abdel Baset [18] and Tyl et al. [15] who have determined the maximum dose of BPA $(75 \mathrm{ppm}$, $5 \mathrm{mg} / \mathrm{kg} /$ day) with no side effects in adults. This 
dose was confirmed by the International Food Safety Authorities Network (INFOSAN) (Network 2009).

In the present study, the apparent increase in vascular wall thickness in the BPA-administrated group (group III) could be due to the effect of ROS on smooth muscle in the blood vessel wall, where it induced the release of cyclophilin A, which stimulated cell division, migration and inflammatory cell infiltration as explained by Satoh et al. [42] and Naif et al. [27]. Moreover, the marked blood vessel congestion and inflammatory cell infiltration in the BPA-administrated group may be due to the stimulation of macrophages by BPA to release inflammatory cytokines, which enhanced the release of other mediators that caused neutrophil accumulation and migration outside blood vessel [43].

There was a significant increase in the interalveolar septum thickness of group III when compared with the other groups; this can be explained by increased infiltration of various blood components such as macrophages and neutrophils [44] This was supported by a significant increase in lung MPO activity and plasma LDH in group III. Vit $\mathrm{E}$ administration in group IV ameliorated these levels. The MPO activity is a signal of tissue neutrophil infiltration [45]. Also, the presence of LDH served as a non-specific marker for many pathological conditions; as it is an intracellular enzyme and its presence in the extracellular space could suggest breakdown of cell integrity or lysis [46]. Lung parenchymal or local inflammatory cells including alveolar macrophages (AM) and polymorphonucleocytes (PMNs) might be a source of LDH in plasma [47]. Raised LDH values had been detected in immunologically lung injury, as well as pulmonary vascular disease [48]

BPA exposure in this study resulted in marked collagen deposition around blood vessels, bronchioles and alveolar wall, also; there was a statistically significant increase in the area percent of collagen. Ramos, et al. [49] showed that hyperplasia occurred due to increase the fibroblast activity in response to BPA. In addition, it injured the epithelial cells and basement membrane which attracted different cell types that released inflammatory cytokines leading to increase in collagen production. The decrease in fibrosis of lung tissues by vitamin $\mathrm{E}$ can be due to down regulation of pro-fibrotic and pro-inflammatory genes expression mostly [transforming growth factor (TGF)- $\beta$ 1] [50,51]
Moreover, the statistically significant increase in the macrophages number was proved by $\mathrm{CD} 68$ immunohistochemistry and calculated by morphometry in group III compared with other groups. This might be attributed to the consecutive division or stimulation of monocytes by various chemotactic factors created from the damaged tissue [52]

$\mathrm{NF}-\kappa \mathrm{B}$ is an inducible cytoplasmic transcription element that positively controls the expression of TNF- $\alpha$, IL- 6 , and IL- $1 \beta$ genes which involved in inflammatory responses $[\mathbf{5 3 , 5 4}]$. Its nuclear translocation and interaction with DNA is inhibited by tight regulatory protein $(\mathrm{I} \kappa \mathrm{B}-\kappa)[\mathbf{5 5 , 5 6}]$. The darkly brown stained NF- $\kappa B$ immunopositive cells in group (III) were markedly increased compared with other groups. Many studies have proved that BPA augments NF- $\kappa \mathrm{B}$ activity and may act as a pro-inflammatory inducer of estrogen receptor $(\mathrm{ER} \beta)$ [57] and also modulates immunoregulatory cells [58]

Current study showed that BPA increased the plasma levels of TNF- $\alpha$, IL- 6 , and IL- $1 \beta$ which induced lung inflammation. IL-1 $\beta$, is an immune responses regulator capable of recruiting inflammatory cells [59]. Also, TNF- $\alpha$ is associated with leukocyte activation and local inflammatory responses [60]. Elswefy et al. [61] stated that BPA significantly elevated the serum level of IL-1 $\beta$ Also, it may influence mast cell pro-inflammatory mediator production in asthma [62]. Consistent to these reports, the present study recorded significant increase in the plasma inflammatory cytokines in group III. While, Vit E treatment in group IV slightly improved these results. As observed by Kosmidou et al. [63] and Lira et al. [64] also stated that vitamin $\mathrm{E}$ diminished IL- 6 and TNF- $\alpha$ production in adipose tissue of epididymis.

NADPH oxidase and xanthine oxidase are the source of $\mathrm{O}_{2}$ and $\mathrm{H}_{2} \mathrm{O}_{2}$ that leads to inflammatory cytokine production intracellularly. Taken together, vitamin $\mathrm{E}$ might reduce their activities, thus reduce TNF- $\alpha$ and IL- 6 production [65]. Matsunaga et al. [66] demonstrated that Vitamin E prevented the I $\kappa \mathrm{B}-\alpha$ degradation and NF- $\kappa \mathrm{B}$ activation, which resulted in reduction of IL-6.

In the present study, alveolar collapse and infiltration with fat cells in group III were detected. The fatty infiltration is explained by Marmugi et al. [67] who reported the effect of BPA on lipogenesis-related genes stimulation. Alveolar collapse has been explained by many authors as stemming from the stimulation of lipid peroxidation in type II pneumocytes, which decreased surfactant for- 
mation, subsequently leading to alveolar collapse. In addition, degenerative changes occurred due to ROS stimulation in type II pneumocytes [68] . It might also be the pressure effect of the dilated alveoli [69].

The outcomes of this study revealed a significant reduction in catalase activity in group III. Similarly, Banerjee et al. [70] showed that BPA exposed rats pretreated with a CAT inhibitor are associated with functional status of ovarian granulosa. CAT is an enzyme that catalyzes the breakdown of $\mathrm{H}_{2} \mathrm{O}_{2}$ to water and oxygen. $\mathrm{H}_{2} \mathrm{O}_{2}$ is capable of passing through cell membranes, leading to greater cytotoxicity than that of superoxide. So, CAT can be labeled as a more powerful antioxidant than SOD [71].

Geetharathan et al. [30] illustrated that oxidative lung damage results in apoptotic damage of alveolar type II cells. We observed significant elevation in the caspase- 3 activity in group III, proposing that apoptosis is caspase- 3 dependent. It is a vital molecular indicator of apoptotic signaling, is initiated by mitochondrial or death receptor apoptotic pathways. It cleaves proteins lead to chromatin condensation and DNA fragmentation [72] .

Depletion of intracellular GSH by BPA resulted in mitochondrial damage, caspase activation and cytochrome c release [73]. Nakagawa et al. [74] described that BPA encouraged mitochondria dysfunction in the hepatocytes of rats. Also, enhanced apoptosis and disrupted cell-to-cell communication [75].

Caspase- 3 activity was reduced by Vit $\mathrm{E}$ in group IV. Omran et al. [76] presented that vitamin $E$ defends rat testes against damaging effect of BPA. These results imply that it may be due to inhibition of the mitochondrial initiated caspase pathway.

Also, this study found that arterial $\mathrm{PaO}_{2}$ significantly decreased and $\mathrm{PaCO} 2$ significantly increased in group III. Campo et al. [77] illustrated that $\mathrm{CO} 2$ retention may lead to poor breathing, hypoxia. Direct degeneration of normal lung tissue and partial loss of lung function by BPA which lead to disturbance of blood gas index, but indirect BPA effect on medullary cardio-respiratory centers is still needed to be examined.

Previous studies have suggested that BPA may have a role in hypertension progression and tachycardia in rats which proved by group III results of this study. Several mechanisms could explain these observations including BPA's role in obesity
[78], estrogen role [79], probable ER-gamma interactions [80], antagonistic actions to thyroid hormone [82], antagonistic role to [peroxisome proliferator activated receptor gamma] [82], and its influence on pancreatic functions [83]. Vit $\mathrm{E}$ ameliorated these hemodynamic effects induced by BPA, suggesting that it could be used as prophylactic agent. Baradaran et al. [84] proved that during hypertension oxidative stress and inflammation are strictly related to metabolic syndrome (MS); therefore factors that ameliorate these agents should play a role in regulation of MS. This idea encouraged examination on vitamin $E$ health benefits. In the present study, co-administration of vitamin $\mathrm{E}$ with BPA in group IV rats alleviated the disturbances in redox status, inflammatory cytokines, and changes in hemodynamics and lung function to a great degree. It also reflected amelioration of histopathological appearance of lung tissues including the inflammatory findings, vascular congestion, and collagen fibre deposition.

Limitations of this study include the small number of rats used; the species difference and thus studies on human may have different results. Finally, blood levels of vitamin E were not investigated in this study and thus the effect of BPA on vitamin $\mathrm{E}$ blood level could also be evaluated in future studies.

\section{Conclusion:}

This study is concerned with the anti-oxidant and anti-inflammatory properties of vitamin $\mathrm{E}$ and how it reduces the toxic effect of BPA. It is therefore proposed that the dietary supplementation with vitamin E may act against BPA-induced lung injury. Thus, it is recommended to shift to other safer product for use in food and water packing and also to investigate the pulmonary functions regularly throughout our life if using plastic containers. Also, further studies should investigate the changes in blood levels of vitamin E in BPA-induced lung injury.

\section{Conflict of interest:}

No conflict of interest to declare.

\section{Fund:}

No fund was received for the study.

\section{Contribution of authors:}

All the authors contributed in preparation of the manuscript. 


\section{References}

1- ESPLUGAS R., LLOVET M.I., BELLÉS M., SERRA N., VALLVÉ J.C., DOMINGO J.L. and LINARES V.: Renal and hepatic effects following neonatal exposure to low doses of Bisphenol-A and 137Cs. Food and Chemical toxicology, 114: 270-277, 2018.

2- HENGSTLER J., FOTH H., GEBEL T., KRAMER P.-J., LILIENBLUM W., SCHWEINFURTH H. and GUNDERT-REMY U.: Critical evaluation of key evidence on the human health hazards of exposure to bisphenol A. Critical Reviews in Toxicology, 41 (4): 263-291, 2011.

3- HEINDEL J.J., NEWBOLD R.R., BUCHER J.R., CAMACHO L., DELCLOS K.B., LEWIS S.M. and McLELLEN M.: NIEHS/FDA CLARITY-BPA research program update. Reproductive Toxicology, 58: 33-44, 2015.

4- CALAFAT A.M., YE X., WONG L.Y., REIDY J.A. and NEEDHAM L.L.: Exposure of the US population to bisphenol A and 4-tertiary-octylphenol: 2003-2004. Environmental Health Perspectives, 116 (1): 39-44, 2007.

5- KANG J.H., KONDO F. and KATAYAMA Y.: Human exposure to bisphenol A. Toxicology, 226 (2-3): 79-89, 2006.

6- BOSNJAK I., BORRA M., IAMUNNO F., BENVENUTO G., UJEVIC, I., BUSELIC, I. and MLADINEO I.: Effect of bisphenol A on P-glycoprotein-mediated efflux and ultrastructure of the sea urchin embryo. Aquatic Toxicology, 156: 21-29, 2014.

7- TAMIYA T., KASHIWAGI I., TAKAHASHI R., YASUKAWA H. and YOSHIMURA A.: Suppressors of cytokine signaling (SOCS) proteins and JAK/STAT pathways: regulation of T-cell inflammation by SOCS1 and SOCS3 Arteriosclerosis, Thrombosis, and Vascular Biology, 31 (5): 980-985, 2011

8- HOU S., DING H., LV Q., YIN X., SONG J., LANDÉN N.X. and FAN H.: Therapeutic Effect of Intravenous Infusion of Perfluorocarbon Emulsion on LPS-Induced Acute Lung Injury in Rats. Plos One, 9 (1): e87826, 2014.

9- LIU W., JIANG H.L., CAI L.L., YAN M., DONG S.J. and MAO B.: Tanreqing Injection Attenuates Lipopolysaccharide-Induced Airway Inflammation through MAPK/NF-kB Signaling Pathways in Rats Model. Evid Based Complement Alternat Med., Vo. 2016, Article ID 5292346, 15 Pages, 2016.

10- S.D. YOO, SHIN B.S., et al.: "Pharmacokinetic disposition and tissue distribution of bisphenol $\mathrm{A}$ in rats after intravenous administration". Journal of toxicology and environmental health Part A, 61 (2): 131-139, 2000.

11- ITO Y., SATO S., SON M., KONDO M., KUME H., TAKAGI K. and YAMAKI K.: Bisphenol A inhibits Clsecretion by inhibition of basolateral $\mathrm{K}+$ conductance in human airway epithelial cells. Journal of Pharmacology and Experimental Therapeutics, 302 (1): 80-87, 2002.

12- SRIVASTAVA S. and GUPTA P.: Genotoxic and Infertility Effects of Bisphenol A on Wistar Albino rats. Int. J. Pharm. Sci. Rev. Res., 41 (1): 126-131, 2016.

13- PEKINER B.D.: Vitamin E as an antioxidant. J. Fac. Pharm. Ankara, 32 (4): 24-267-3, 2003.

14- OGUTCU A., UZUNHISARCIKLI M., et al.: "The effects of organophosphate insecticide diazinon on malondialdehyde levels and myocardial cells in rat heart tissue and protective role of vitamin E." Pesticide Biochemistry and Physiology, 86 (2): 93-98, 2006.

15- TYL R.W., MYERS C.B., MARR M.C., THOMAS B.F., KEIMOWITZ A.R., BRINE D.R. and JOINER R.L.: Three-generation reproductive toxicity study of dietary bisphenol A in CD Sprague-Dawley rats. Toxicological Sciences, 68 (1): 121-146, 2002.

16- CHAPIN R.E., ADAMS J., BOEKELHEIDE K., GRAY JR., L.E., HAYWARD S.W., LEES P.S. and SELEVAN S.G.: NTP-CERHR expert panel report on the reproductive and developmental toxicity of bisphenol A. Birth Defects Research Part B: Developmental and Reproductive Toxicology, 83 (3): 157-395, 2008.

17-ABUBAKAR M.G., UKWUANI A.N. and MANDE U.U.: Antihypertensive activity of Hibiscus Sabdariffa aqueous calyx extract in Albino rats. Sky Journal of Biochemistry Research, 4 (3): 16-20, 2015.

18- KATTAIA A.A. and BASET S.A.A.: Effect of bisphenol $A$ on the lung of adult male albino rats and the possible protective role of geraniol: A histological and immunohistochemical study. Egyptian Journal of Histology, 37 (1): $24-35,2014$.

19- YING Y., XU H., YAO M. and QIN Z.: Protective effect of hydrogen-saturated saline on acute lung injury induced by oleic acid in rats. Journal of Orthopaedic Surgery and Research, 12 (1): 134, 2017.

20- OHKAWA H., OHISHI N. and YAGI K.:. Assay for lipid peroxides in animal tissues by thiobarbituric acid reaction. Analytical Biochemistry, 95 (2): 351-358, 1979.

21- KAKKAR P., DAS B. and VISWANATHAN P.N.: A modified spectrophotometric assay of superoxide dismutase, 1984

22- LÜCK H.: Catalase. In Methods of enzymatic analysis (pp. 885-894). Academic Press, 1965.

23- REDDY K.P., SUBBANI S.M., KHAN P.A. and KUMAR K.B.: Effect of light and benzyl adenine in dark trated growing leaves, changes in the peroxidase activity. Cell Physiol., 29, 984, 1995.

24- KIERNAN J.A.: Histological and histochemical methods: Theory and practice. Shock, 12 (6): 479, 1999.

25- BANCROFT J. and GAMBLE M.: Connective tissue stains. Theory and Practice of Histological Techniques. J. Bancroft, editor. Churchill-Livingston Elsevier, London, 135-160, 2008.

26- RAMOS VARA J.A., KIUPEL M., BASZLER T., BLIVEN L., BRODERSEN B., CHELACK B., et al.: American association of veterinary laboratory diagnosticians subcommittee on standardization of immunohistochemistry: Suggested guidelines for immunohistochemical techniques in veterinary diagnostic laboratories. J. Vet. Diagn. Invest, 20: 393-413, 2008 .

27- NAIF A. AL-GABRI, ABDEL-MONEIM ALI, ELSAYED AL-ATTAR and MOHAMMED HAMED: Pathological Study on the Role of Thymoquinone in Experimentally Induced Acute Lung Injury in Rats. http://doi.org/ 10.5281/zenodo.999556, 2017.

28- PETRIE A. and SABIN C.: Basic techniques for analysing data. Medical statistics at a glance. 2 nd edn. Oxford: Blackwell, 46-101, 2005. 
29- DELATTRE J., BEAUDEUX J.L. and BONNEFONTROUSSELOT D.: Radicaux libres et stress oxydant (aspects biologiques et pathologiques), 2005.

30- GEETHARATHAN T. and PEERA K.: Effect of bisphenola on the cardiovascular system in pregnant rats. International Journal of Pharmaceutical Sciences and Research, 9 (11): 4690-4695, 2018.

31- RAHMAN I., BISWAS S.K., et al.: "Oxidant and antioxidant balance in the airways and airway diseases." European Journal of Pharmacology, 533 (1-3): 222-239, 2006.

32- SONG S., ZHANG L., ZHANG H., WEI W. and JIA L.: Perinatal BPA exposure induces hyperglycemia, oxidative stress and decreased adiponectin production in later life of male rat offspring. International Journal of Environmental Research and Public Health, 11 (4): 3728-3742, 2014.

33- ABEDELHAFFEZ A.S., EL-AZIZ E.A.A., et al.: "Lung injury induced by Bisphenol A: A food contaminant, is ameliorated by selenium supplementation". Pathophysiology, 24 (2): 81-89, 2017.

34- GRUNE T., SIEMS W. G. and PETRAS T.: Identification of metabolic pathways of the lipid peroxidation product 4-hydroxynonenal in in situ perfused rat kidney. Journal of Lipid Research, 38 (8): 1660-1665, 1997.

35- DEMIR S., YILMAZ M., KOSEOGLU M., AKALIN N., ASLAN D. and AYDIN A.: Role of free radicals in peptic ulcer and gastritis. Turkish Journal of Gastroenterology, 14 (1): 39-43, 2003.

36- POMPELLA A., VISVIKIS A., PAOLICCHI A., De TATA V. and CASINI A.F.: The changing faces of glutathione, a cellular protagonist. Biochemical pharmacology, 66 (8): 1499-1503, 2003.

37- SABOUR A.N.: The Effect of Bisphenol A on Some Antioxidants in White male rats. Sci. J. Med. Res, 3 (10): 83-86, 2019.

38- ADEWOYIN M., IBRAHIM M., ROSZAMAN R., ISA M.L.M., ALEWI N.A.M., RAFA A.A.A. and ANUAR M.N.N.: Male infertility: the effect of natural antioxidants and phytocompounds on seminal oxidative stress. Diseases, $5(1), 9,2017$.

39- AMRAOUI W., ADJABI N., et al.: "Modulatory role of selenium and vitamin $\mathrm{E}$, natural antioxidants, against bisphenol A-induced oxidative stress in wistar albino rats". Toxicological Research, 34 (3): 231, 2018.

40- GUEROUI, M. and KECHRID Z.: "Evaluation of some biochemical parameters and brain oxidative stress in experimental rats exposed chronically to silver nitrate and the protective role of vitamin E and selenium". Toxicological Research, 32 (4): 301, 2016.

41- AMARAVATHI P., SRILATHA C., RAMADEVI V., SREENIVASULU D., PRASAD P.E. and SUJATHA K.: Pulmonary and genotoxicity of Bisphenol-A in Wistar albino rats. Curr Biotica, 6: 53-60, 2012.

42- SATOH K., NIGRO P., et al.: "Oxidative stress and vascular smooth muscle cell growth: A mechanistic linkage by cyclophilin A." Antioxidants \& Redox Signaling, 12 (5): 675-682, 2010

43- WETHERILL Y.B., AKINGBEMI B.T., et al.: "In vitro molecular mechanisms of bisphenol A action". Reproductive Toxicology, 24 (2): 178-198, 2007.
44- ZIDAN R.A.: "Effect of long-term administration of amiodarone on rat lung and the possible protective role of vitamin E: A histological and immunohistochemical study". Egyptian Journal of Histology, 34 (1): 117-128, 2011.

45- KETTLE A.J. and WINTERBOURN C.C.: Myeloperoxidase: A key regulator of neutrophil oxidant production. Redox Report, 3 (1): 3-15, 1997.

46- COBBEN N.A.M., DRENT M., SCHOLS A.M.W.J., LAMERS R.J.S., WOUTERS, E.F.M. and VAN DIEIJEN VISSER M.P.: Serum lactate dehydrogenase and its isoenzyme pattern in ex-coalminers. Respiratory Medicine, 91 (10): 616-623, 1997.

47- DRENT M., COBBEN N.A., HENDERSON R.F., WOUTERS E.F. and VAN DIEIJEN-VISSER M.: Usefulness of lactate dehydrogenase and its isoenzymes as indicators of lung damage or inflammation. European Respiratory Journal, 9 (8): 1736-1742, 1996.

48- KHAN D.A., HASHIM R., MIRZA T.M. and RAHMAN M.M.: Differentiation of pulmonary embolism from high altitude pulmonary edema. Journal of the College of Physicians and Surgeons Pakistan: JCPSP, 13 (5): $267-$ 270, 2003

49- RAMOS J.G. and VARAYOUD J., et al.: "Prenatal Exposure to Low Doses of Bisphenol A Alters the Periductal Stroma and Glandular Cell Function in the Rat Ventral Prostate1". Biology of Reproduction, 65 (4): 1271-1277, 2001.

50- CARD J.W., RACZ W.J., BRIEN J.F. and MASSEY T.E. Attenuation of amiodarone-induced pulmonary fibrosis by vitamin $\mathrm{E}$ is associated with suppression of transforming growth factor- $\beta 1$ gene expression but not prevention of mitochondrial dysfunction. Journal of Pharmacology and Experimental Therapeutics, 304 (1): 277-283, 2003.

51- GAWAD F.A.E.R., RIZK A.A.E.E., JOUAKIM M.F. and EL HALEM M.Z.A.: Amiodarone-induced lung toxicity and the protective role of Vitamin $\mathrm{E}$ in adult male albino rat. European Journal of Anatomy, 22 (4): 323-333, 2018.

52- BURKITT H.G., STEVENS A., LOWE J.S. and YOUNG B.: Disease of respiratory system. In: Burkitt H.G., Stevens A., Lowe J.S., Young B., editors. Wheater's basic histopathology: A color atlas and text. 3 rd ed. NY \& Tokyo. Churchill Livingstone, pp. 122-129, 1996.

53- OECKINGHAUS A., HAYDEN M.S. and GHOSH S.: Crosstalk in NF-icB signaling pathways. Nature Immunology, 12 (8): 695, 2011.

54- TORNATORE L., THOTAKURA A.K., BENNETT J., MORETTI M. and FRANZOSO G.: The nuclear factor kappa B signaling pathway: Integrating metabolism with inflammation. Trends in Cell Biology, 22 (11): 557-566, 2012.

55- WANG J., QIAO L., et al.: "Protective effect of ginsenoside $\mathrm{Rb} 1$ against lung injury induced by intestinal ischemiareperfusion in rats". Molecules (Basel, Switzerland), 18 (1): 1214-1226, 2013.

56- LEE S., SUK K., KIM I.K., JANG I. S., PARK J.W., JOHNSON V.J. and KIM S.H.: Signaling pathways of bisphenol A-induced apoptosis in hippocampal neuronal cells: Role of calcium-induced reactive oxygen species, mitogen-activated protein kinases, and nuclear factor- ic $\mathrm{B}$ 
Journal of neuroscience research, 86 (13): 2932-2942, 2008.

57- ZHU J., JIANG L., LIU Y., QIAN W., LIU J., ZHOU J. and WANG J.: MAPK and NF- $\kappa$ B pathways are involved in bisphenol A-induced TNF- $\alpha$ and IL- 6 production in BV2 microglial cells. Inflammation, 38 (2): 637-648, 2015.

58- BONDS R.S. and MIDORO-HORIUTI T.: Estrogen effects in allergy and asthma. Current opinion in allergy and Clinical Immunology, 13 (1): 92, 2013.

59- BONIZZI G. and KARIN M.: The two NF- $\kappa$ B activation pathways and their role in innate and adaptive immunity. Trends in Immunology, 25 (6): 280-288, 2004.

60- GRIFFIN G.K., NEWTON G., TARRIO M.L., BU D.X., MAGANTO-GARCIA E., AZCUTIA V. and LICHTMAN A.H.: IL-17 and TNF- $\alpha$ sustain neutrophil recruitment during inflammation through synergistic effects on endothelial activation. The Journal of Immunology, 188 (12): 6287-6299, 2012.

61- ELSWEFY S.E.S., ABDALLAH F.R., ATTEIA H.H., WAHBA A.S. and HASAN R.A.: Inflammation, oxidative stress and apoptosis cascade implications in bisphenol A_induced liver fibrosis in male rats. International Journal of Experimental Pathology, 97 (5): 369-379, 2016.

62- O'BRIEN E., DOLINOY D.C. and MANCUSO P.: Perinatal bisphenol A exposuresincrease production of proinflammatory mediators in bone marrow-derivedmast cells of adult mice. J. Immunotoxicol., 11: 205-212, 2014.

63- KOSMIDOU I., VASSILAKOPOULOS T., XAGORARI A., ZAKYNTHINOS S., PAPAPETROPOULOS A. and ROUSSOS C.: Production of interleukin- 6 by skeletal myotubes: Role of reactive oxygen species. American Journal of Respiratory Cell and Molecular Biology, 26 (5): 587-593, 2002.

64- LIRA F.S., ROSA J.C., CUNHA C.A., RIBEIRO E.B., DO NASCIMENTO C.O., OYAMA L.M. and MOTA J.F.: Supplementing alpha-tocopherol (vitamin E) and vitamin D3 in high fat diet decrease IL-6 production in murine epididymal adipose tissue and 3T3-L1 adipocytes following LPS stimulation. Lipids in Health and Disease, 10 (1), 37, 2011.

65- KAMISAH Y., IBRAHIM A.A.I., NAFEEZA M.I. and NUR-AZLINA M.F.: Palm tocotrienol-rich fraction supplementation suppressed stress-induced gastric oxidative stress in rats. Journal of Applied Pharmaceutical Science, 1 (10), 118, 2011.

66- MATSUNAGA T., SHOJI A., GU N., JOO E., LI S., ADACHI T. and TSUDA K.: $\gamma$-Tocotrienol attenuates TNF- $\alpha$-induced changes in secretion and gene expression of MCP-1, IL-6 and adiponectin in 3T3-L1 adipocytes. Molecular Medicine Reports, 5 (4): 905-909, 2012.

67- MARMUGI A., DUCHEIX S., LASSERRE F., POLIZZI A., PARIS A., PRIYMENKO N. and MSELLI-LAKHAL L.: Low doses of bisphenol A induce gene expression related to lipid synthesis and trigger triglyceride accumulation in adult mouse liver. Hepatology, 55 (2): 395-407, 2012.

68- KOLLECK I., SINHA P. and RÜSTOW B.: Vitamin E as an antioxidant of the lung: Mechanisms of vitamin $\mathrm{E}$ delivery to alveolar type II cells. American journal of respiratory and critical care medicine, 166 (Supplement 1): S62-S66, 2002.

69- POPOV D. and SIMIONESCU M.: "Alterations of lung structure in experimental diabetes, and diabetes associated with hyperlipidaemia in hamsters". European Respiratory Journal, 10 (8): 1850-1858, 1997.

70- BANERJEE O., SINGH S., PRASAD S.K., BHATTACHARJEE A., BANERJEE A., BANERJEE A. and MUKHERJEE S.: Inhibition of catalase activity with 3amino-1, 2, 4-triazole intensifies bisphenol A (BPA)induced toxicity in granulosa cells of female albino rats. Toxicology and Industrial Health, 34 (11): 787-797, 2018.

71- IGHODARO O.M. and AKINLOYE O.A.: First line defence antioxidants-superoxide dismutase (SOD), catalase (CAT) and glutathione peroxidase (GPX): Their fundamental role in the entire antioxidant defence grid. Alexandria Journal of Medicine, 54 (4): 287-293, 2018.

72- CHOI Y.H., BAEK J.H., YOO M.A., CHUNG H.Y., KIM N.D. and KIM K.W.: Induction of apoptosis by ursolic acid through activation of caspases and down-regulation of c-IAPs in human prostate epithelial cells. International Journal of Oncology, 17 (3): 565-636, 2000.

73- LEON J., ACUÑA-CASTROVIEJO D., ESCAMES G., TAN D.X. and REITER R.J.: Melatonin mitigates mitochondrial malfunction. Journal of Pineal Research, 38 (1): 1-9, 2005.

74- NAKAGAWA Y. and TAYAMA S.: Metabolism and cytotoxicity of bisphenol A and other bisphenols in isolated rat hepatocytes. Archives of Toxicology, 74 (2): 99-105, 2000.

75- JEMEC A., TISLER T., ERJAVEC B. and PINTAR A.: Antioxidant responses and whole-organism changes in Daphnia magna acutely and chronically exposed to endocrine disruptor bisphenol A. Ecotoxicology and Environmental Safety, 86: 213-218, 2012.

76- OMRAN B.H., ABDALLAH E.A. and ABDELWAHAB M.M.: Study of Probable Toxic Effects of Bisphenol A $\&$ the Protective Role of Vitamin E on Testes and Prostate of Adult Male Albino Rats. Ain Shams Journal of Forensic Medicine and Clinical Toxicology, 29: 7-18, 2017.

77- CAMPO G., PAVASINI R., MALAGÙ M., MASCETTI S., BISCAGLIA S., CECONI C. and CONTOLI M.: Chronic obstructive pulmonary disease and ischemic heart disease comorbidity: Overview of mechanisms and clinical management. Cardiovascular drugs and Therapy, 29 (2): 147-157, 2015.

78- PHRAKONKHAM P., VIENGCHAREUN S., BELLOIR C., LOMBES M., ARTUR Y. and CANIVENC-LAVIER M.C.: Dietary xenoestrogens differentially impair 3T3L1 preadipocyte differentiation and persistently affect leptin synthesis. The Journal of Steroid Biochemistry and Molecular Biology, 110 (1-2): 95-103, 2008.

79- RUBIN B.S. and SOTO A.M.: Bisphenol A: Perinatal exposure and body weight. Molecular and Cellular Endocrinology, 304 (1-2): 55-62, 2009.

80- MATSUSHIMA A., TERAMOTO T., OKADA H., LIU X., TOKUNAGA T., KAKUTA Y. and SHIMOHIGASHI Y.: ERR $\gamma$ tethers strongly bisphenol A and 4- $\alpha$ cumylphenol in an induced-fit manner. Biochemical and Biophysical Research Communications, 373 (3): 408413, 2008. 
81- MORIYAMA K., TAGAMI T., AKAMIZU T., USUI T., SAIJO M., KANAMOTO N. and NAKAO K.: Thyroid hormone action is disrupted by bisphenol $\mathrm{A}$ as an antagonist. The Journal of Clinical Endocrinology \& Metabolism, 87 (11): 5185-5190, 2002.

82- WRIGHT H.M., CLISH C.B., MIKAMI T., HAUSER S., YANAGI K., HIRAMATSU R. and SPIEGELMAN B.M.: A synthetic antagonist for the peroxisome proliferatoractivated receptor y inhibits adipocyte differentiation. Journal of Biological Chemistry, 275 (3): 1873-1877, 2000.
83- ROPERO A.B., ALONSO-MAGDALENA P., GARCIAGARCIA E., RIPOLL C., FUENTES E. and NADAL A.: Bisphenol-A disruption of the endocrine pancreas and blood glucose homeostasis. International Journal of Andrology, 31 (2): 194-200, 2008.

84- BARADARAN A., NASRI H. and RAFIEIAN-KOPAEI M.: Oxidative stress and hypertension: Possibility of hypertension therapy with antioxidants. J. Res. Med. Sci., 19: 358-367, 2014.

\section{الدور المحتمل لفيتامين هاء فى وقاية ربئة ذكر الجرذ الأبيض البالغ

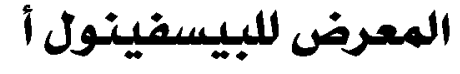

المقدمة: البيسفينول أ هى مادة كيميائية مصنعة توجد فى جميع أنحاء العالم وتدخل فى صناعة البلاستيك وقد يؤدى التعرض لها من

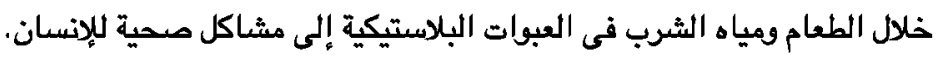

الهدف: تهدف هذه الدراسة إلى استكثاف الدود الوقائى المحتمل لفيتامين هاء ضد التغيرات الوظيفية والهيكلية التى تحدث فى رئة ذكود

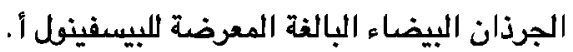

المواد والطرق المستخدمة: تم تقسيم أربعة وعشرين فأراً من ذكر الجرذان اليضاء البالغة إلى أربعة مجموعات متساوية تككون كل منها من اجرذان:

- المجموعة الأولى الضابطة: تنقسم إلى مجموعتين فرعيتين المجموعة الفرعية (أ) مجموعة المرآبة السلبية تتفذى على نظام عذائى منتظم

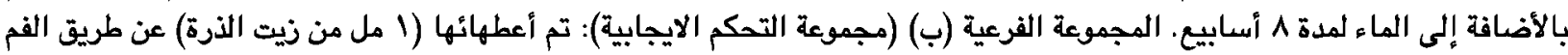
في اليوم لمدة 1 أسابيع. - الهجموعة الثانية تلقت (فيتامين هاء وحدة): . .ب ملغ من فيتا مين هاء / كجم / يوم. - المجموعة الثائة تلقت (بيسفينول أ): . 0 ملغ من البيسفينول / كجم / يوم.

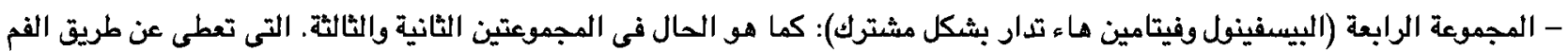

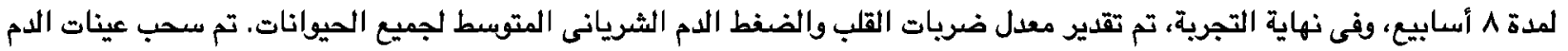

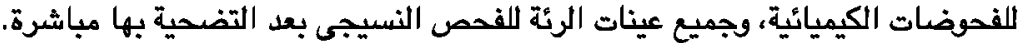

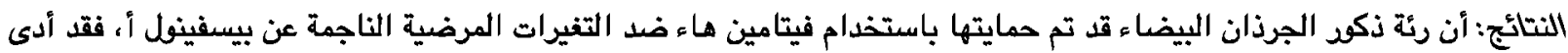

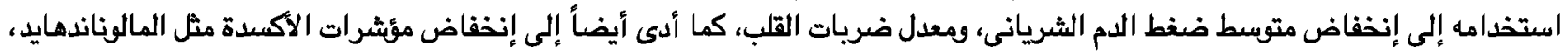

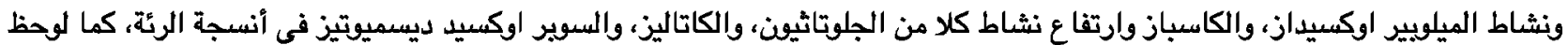

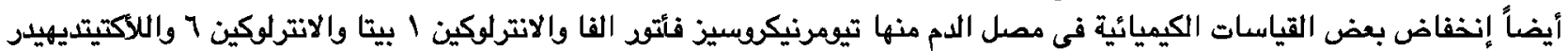

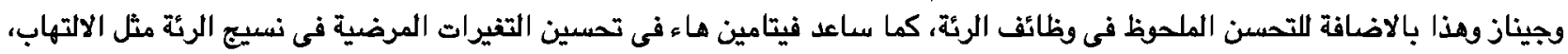

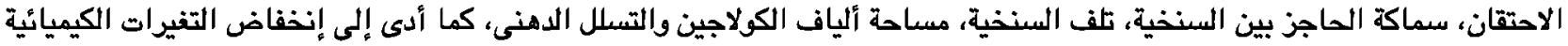
المناعية فى التمايز \T والعامل النويى فى الخلايا المناعية لأنسجة الرئة.

الخلاصة: أن التعرض البيسفينول نجم عنه ارتفاع فى مؤشرات الاكسدة واختلال وظائف الرئة وإصابة نسيج الرئة بالضرر، وقد كانت هذه التغيرات أقل بشكل ملحوظ عن طريق استخدام فيتامين هاء الذيى هو احدى المكملات التهات الغذائية. 